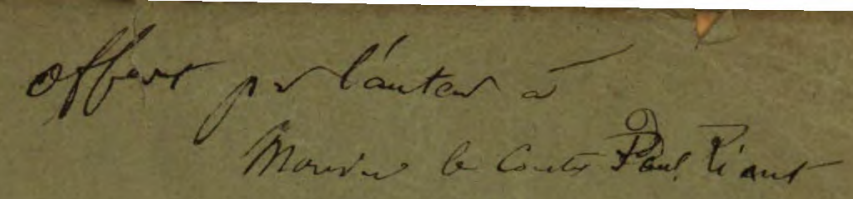

DES PĖLERINAGES

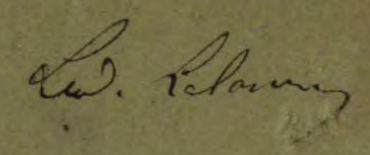

E. N

\title{
TERRE SAINTE
}

AVANT LES CROISADES,

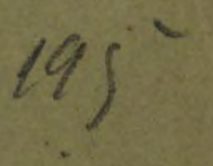

\section{PAR LUDOVIC LALANNE,}

Ancien Élève de l'École des Chartes.

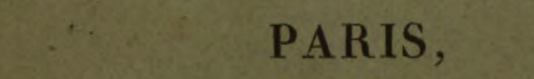

TYPOGRAPHIE DE FIRMIN DIDOT FRÈRES, RUE JACOB, 56 . 